\title{
THE NORTH CAUCASUS IN JANUARY-MAY 2013: THE KEY RISKS
}

\author{
K.Kazenin
}

In the first few months of 2013, the North Caucasus continued to be plagued by the same core unresolved issues that are the main source of tension in that region. Thus, in particular, no systemic solution has yet been provided to the ongoing conflicts in the land sphere, which are further aggravated by the persisting controversies in the Islamic community and a high level of extremist crime. The most serious currently existing risks associated with these unresolved issues have to do with land development in the framework of health resort construction projects, as well as with the increasing interconnection between extremist crime and the so-called 'economic conflicts'.

\section{Health Resorts: The Land Issue}

In the North Caucasus, the implementation of the ski resort 'tourism cluster' is continuing. The principal operator of that project is OJSC Kurorty Severnogo Kavkaza [Health Resorts of the North Caucasus] (KSK), whose controlling block of shares is held by the State. In accordance with the project's blueprint presented in 2010 and adjusted in 2011, the cluster is to include 6 stateof-the-art alpine ski resorts: Matlas (Dagestan), Armkhi (Ingushetia), Mamison (North Osetia), Elbrus-Bezengi (Kabardino-Balkaria), Arkhyz (Karachaevo-Cherkessia), and Lago-Naki (Adygea). The main 'image-making' news from the tourism cluster over the first 5 months of 2013 has become the opening of the first alpine ski track at Armkhi in February ${ }^{1}$. However, Armkhi can hardly be regarded, in economic terms, as the cluster's core component. Firstly, this health resort complex is situated at the altitude of approximately 1,500 $\mathrm{m}$ where the snow cover is unstable even in winter (it is typical that the date of the opening ceremony was moved because of absence of snow). Secondly, the complicated general situation (including the level of crime) in Ingushetia coupled with the fact that the new health resort lacks a recognizable brand name leave little reason to hope for any more or less significant inflow of tourists from other regions. Evidently it was with this circumstance in view that the region's head Yunus-bek Yevkurov had said prior to the opening of Armkhi that the health resort would 'first of all, make it possible to satisfy the domestic demand'.

In the other areas (with better economic prospects) included in the alpine ski cluster - the health resorts situated in the West Caucasus, where the snow cover is more stable and stays for a longer period, and so it had been regularly visited by tourists from different regions all over Russia even before the onset of the cluster's construction, no new facilities were put in operation in the first 5 months of 2013.

However, it appears to be more important that the serious controversies which arose in connection with the impending implementation of new health resort projects have never been properly dealt with. Thus, for example, in Karachaevo-Cherkessia, where the first hotels at the Arkhyz health resort capable of receiving a total of 25,000 tourists will already be opened this summer, no clarity has been achieved with regard to the protection of the business interests of the Dombai health resort, which is faced with the risk of losing a substantial part of its tourist inflow after Arkhyz is put in operation. As shown in the Gaidar Institute's annual economic overview ${ }^{3}$, any serious drop in the inflow of tourists to Dombai is fraught with the risk of significant upsurge in social - and perhaps also political tension, because Dombai is a key source of employment for a greater part of the Karachaevo city district and Karachaevo municipal raion, while many of the

1 Otkrytie kurorta Armkhi $v$ Ingushetii pereneseno na 5 fevralia [The opening of the Armkhi health resort is postponed until 5 February] // Kavkazskii uzel [The Caucasian Knot], 25 January 2013 (http://www.kavkaz-uzel.ru/articles/219158/).

2 V kontse 2012 goda kurort Armkhi primet pervykh turistov [In late 2012, the Armkhi health resort will receive the first tourists] // ITAR-TASS, 27 February 2012 (http://www.itar-tass.com/c30/353166.html).

3 Russian Economy in 2012. Trends and Outlooks. (Issue 34) - M.: Gaidar Institute Publishers, 2013. Section 6.7. 
hotel-owning families in this health resort also enjoy a considerable political influence in the republic.

Another unresolved issue associated with health resorts in the West Caucasus has to do with land relations. This issue is most acutely felt in Kabardino-Balkaria, where it is planned to open health resorts in the vicinity of land that have been traditionally used by local residents for their traditional farming needs. The events of the last few months have demonstrated that the absence of a transparent and clearly defined procedure for coordinating the land-related decision-making process with the local residents is a manifestation of the existing systemic problem, and not the result of a faulty preparation of one or other administrative decision. It should be reminded that the first alarm bells were sounded in connection with the situation in the mountain village of Bezengi in Cherek raion, where in the autumn of 2012 five deputies of the local self-government body gave up their mandates in response to the unlawful (in their opinion) alienation of land for the planned health resort construction that had always historically belonged to Bezengi. At the very end of 2012, another news came from the same area now the deputies of one of the villages situated in Zolsky raion were also protesting against the seizures of land by resort developers. It is true that the situation there was less acute than at Bezengi: the deputies did not go as far as giving up their mandates, and later on they even renounced their own declarations that a ban should be imposed on any land being handed over to the construction projects ${ }^{1}$. Nevertheless, according to available data, in the winter and spring of 2013 the communities of those rural settlements situated in Zolsky raion whose lands are to be covered by the future construction projects, similarly to the residents of the village of Bezengi, were still expecting the specific information to be released by OJSC Kurorty Severnogo Kavkaza (KSK) concerning the exact boundaries of the planned health resort areas. According to them, they have so far received no more or less coherent explanations as to the health resort boundaries or the amount of compensation for the potential loss of their lands.

At present, the core problem in health resort construction is the noticeable opposition on the part of local residents coupled with lack of any procedures for carrying on a dialogue on land issues. Given the acuteness of the land-related conflicts in different regions across the North Caucasus, it is evidently dangerous to continue to make any plans concerning the earmarking of territories for future health resorts in a non-transparent mode. In May, information was released that the government of Kabardino-Balkaria was coordinating 'the issue of implementing cadastre and land development work, as well as elaborating the draft plan for outlining the territory of the special economic zone for OJSC $K S K^{2}$. So far, it has remained unknown just how the interaction with the related rural communities is going to be organized in the course of these planned activities. It seems that the practical approaches of the management of OJSC KSK (where changes currently are under way after Akhmed Bilalov, chairman of its board of directors, has left his post) will actually determine whether the new alpine ski cluster is going to become a serious catalyst of tension in that region.

\section{Islam: Stagnation in the Dialogue and 'Fragmentation' of Conflicts}

Islam plays a prominent role in all the regions of the North Caucasus, but we in our overview will limit the discussion to the situation in Dagestan, where Islam not only determines spiritual life, but is a factor that regulates the existing social relations and ongoing conflicts. The split inside Dagestan's Muslim community that had become visible in the second half of the 1990s, gave rise to a tough competition between different Islamic centers for informal control over many facets of the region's life. As part of their response to the increasing confrontation, the Dagestan authorities in 2010 put forth a number of initiatives aimed at starting an intra-Islamic dialogue, which marked a departure of their former orientation to the support of only one branch of Islam (Sufism) as a 'traditional' one for Dagestan. When, in late January 2013, Ramazan Abdulatipov was appointed

1 Deputaty Zol'skogo raiona Kabardino-Balkarii ne zapreshchali stroitel'stvo turklastera [The deputies of Zolsky raion of Kabardino-Balkaria did not ban the construction of a tourism cluster] // IA REGNUM, 4 December 2012 (http://regnum.ru/news/1600606.html).

2 V Kabardino-Balkarii pristupili k planirovke territorii osoboi ekonomicheskoi zony [In Kabardino-Balkaria, the planning of the territory of a special economic zone has started] // IA REGNUM, 14 May 2013 (http://regnum.ru/news/1658306.html). 
acting president of Dagestan, it became essential to understand which approach to Islamic issues the region's new authority would actually choose.

On the whole, it can be said that so far no choice has been made - at least, on a public level. Such a conclusion may be drawn on the basis of Abdulatipov's very controversial statements on this subject. Thus, at one of the government meetings in March, he declared that it was necessary to carry out a certification of the imams of all mosques in the region ${ }^{1}$. Such a procedure (which has already been announced in some other RF republics) is invariably perceived as a measure designed to ensure the government's active involvement in religious teachings. However, less than two months after that declaration, Abdulatipov puts forth another principle as a basis for the interaction between the republic's authorities and the Muslim community, this time rejecting the possibility of such interference: 'We are not going to ban various branches [of Islam]. The most important thing for us is that they must abide by the Russian laws. If all this is done within the framework of Russia's laws, it will be none of our business which way one or other person prays, or which traditions and rites he observes. The essential thing for us is that religion must not be applied as a means in the struggle against the State'2.

It should be noted that the uncertain standpoint of the republic's authorities with regard to Islamic issues is observed against the backdrop of the loss of human resources that occurred, for various reasons, in all the main schools and branches of Islam in Dagestan in the course of last year $(2012)^{3}$. This circumstance - even if the region's authority will indeed decide to revive the dialogue - makes it doubtful that the government will be actually capable of forming efficient 'dialogue teams' whose authority can be unquestionably accepted by all Islamic believers.

Alongside the uncertain prospects of the revival of a dialogue between different legally established 'centers' of the local branches of Islam, the region is now faced with an increasing scale of extremist crime. Some already existing trends in that sphere have become more prominent. We mean the strengthening of the sources of tension in some villages, which are also sites of some serious 'economic' conflicts.

For example, in March and April tension was on the rise at the village of Gymry in Untsukul raion: in the course of a special operation in Makhachkala launched on 19-22 March, leader of the so-called Gymry Jamia Ibragim Gadjidadaev was killed ${ }^{4}$, and then in April a large-scale special operation was launched at Gymry itself, during which several activists of the local bandit underground who were actively resisting the law enforcement teams were also killed. The escalation of violence at Gymry takes place against the backdrop of other, no less acute problems that have to do with the payment of compensation to local residents for the loss of lands and houses as a result of the creation of a reservoir near the village ${ }^{5}$.

One more example is the situation at the village of Khadjalmakhi in Levasha raion, where the spring of 2013 saw an extreme conflict between the village's religious groups, with murders and mutual accusations of murders ${ }^{6}$. Simultaneously, the village was shaken by another grave conflict connected with a financial pyramid organized by some of its residents, who had accumulated billions of rubles in the form of contributions collected in various raions of Dagestan ${ }^{7}$. The situation is indeed explosive because, according to available data, the creators of the financial pyramid are known as the adepts of one of the schools of Islam that has its followers amongst

1 Ramazan Abdulatipov: Nado provesti attestatsiiu imamov mechetei [Ramazan Abdulatipov: It is necessary to conduct a certification of the imams of mosques] // RGVK [Russian Television Briadcasting Channel] Dagestan, 1 March 2013 (http://www.rgvktv.ru/news/18404).

2 Ramazan Abdulatipov, i. o. prezidenta Dagestana: 'Vsekh moikh predshestvennikov sozhrali klany' [Ramazan Abdulatipov, Acting Prezident of Dagestan: 'All my predecessors were devoured by the clans] // Komsomol'skaia pravda [The Komsomol Truth], 30 April 2013.

3 Russian Economy in 2012. Trends and Outlooks. (Issue 34) - M.: Gaidar Institute Publishers, 2013. Section 6.7.

4 Ubit odin iz liderov Dagestanskogo bandpodpol'ia? [One of the leader of Dagestan bandit underground has been killed?] // IA REGNUM, 21 March 2013 (http://regnum.ru/news/1638637.html).

5 See I. V. Starodubrovskaya, D. V. Sokolov. Istoki konfliktov na Severnom Kavkaze [The Sources of conflicts in the North Caucasus]. M: Delo. 2013. P. 150-173.

6 Dagestanskie vlasti oprovergaiut informatsiiu o rasstrel'nykh spiskakh [The Dagestan authorities disprove information on the existence of 'shooting lists'] // IA REGNUM, 13 May 2013 (http://regnum.ru/news/1657849.html).

7 Khadjalmakhinskie piramidy. Pervaia krov' [The Khadjalmakhi pyramids. The first blood] // Kavkazskaia politika [The Caucasus Policy], 6 April 2013 (http://kavpolit.com/xadzhalmaxinskie-piramidy-pervaya-krov/). 
the villagers. So, it is evident that the situation is heated up by the combined effect of religious and economic factors.

The 'parallelism' of religious and economic conflicts can also be observed in other villages and towns across the territory of Dagestan. The evolvement of this trend results in a 'territorial fragmentation' of the initial conflict that has originated between different branches of Islam, in it being adjusted to the versatile specific features typical of the different parts of that North Caucasus region. As this trend becomes stronger, the dialogue-oriented regulatory measures that were practiced in Dagestan in the period of 2010-2012 and envisaged in the main the organization of consultations between the republic-level religious leaders, may no longer work. In order to bring down the level of tension in the religious sphere, some other measures may be needed that will be 'tuned' to the specificities of each relevant village and/or raion and oriented to providing solutions to their existing urgent economic problems. 